\title{
Bacteriology of lacrimal duct obstruction in adults
}

\author{
Jouko Hartikainen, Olli-Pekka Lehtonen, K Matti Saari
}

\begin{abstract}
Aims-To determine the current bacteriology of lacrimal duct obstruction (LDO) and to relate the bacteriological findings to the type of symptoms.

Methods-127 samples were obtained from the lacrimal sac in 118 consecutive adult patients with LDO, including nine bilateral cases.

Results-Altogether, 156 isolates were recovered from the 127 samples cultured. Cultures were positive from $84 \%$ of the samples. Gram positive bacteria were isolated in $79(62 \%)$ samples. The most frequently cultured bacterial species was Staphylococcus epidermidis, representing $27 \%$ of the isolates. Gram negative bacteria were recovered from $26(20 \%)$ samples, and these bacteria were statistically significantly more common in cases with copious discharge than in cases with minor discharge $(p=0.000)$. Cases with simple stenosis of the lacrimal duct (SSLD) showed significantly less Streptococcus sp $(p=0.004)$ and Gram negative organisms $(p=0.004)$ than those with chronic dacryocystitis.

Conclusion-The bacteriology of SSLD resembles that of normal conjunctival flora. Chronic dacryocystitis in adults is associated with an increased proportion of Gram negative bacteria which may be a reservoir for postoperative intraocular infection. They should also be taken into account in selecting antimicrobial prophylaxis in lacrimal drainage surgery. (Br f Ophthalmol 1997;81:37-40)
\end{abstract}

Lacrimal sac and/or nasolacrimal duct obstruction, which here is defined as lacrimal duct obstruction (LDO), is an annoying and sometimes an eye threatening ophthalmic problem, which affects patients of every age. The obstruction may be an idiopathic inflammatory stenosis, the primary acquired nasolacrimal duct obstruction (PANDO), ${ }^{1}$ which mostly affects middle aged and elderly women, or may be secondary to trauma, infection, inflammation, neoplasm, or mechanical obstruction, the secondary acquired lacrimal drainage obstruction (SALDO). ${ }^{2}$ Distal obstruction converts the lacrimal sac into a stagnant pool, which easily becomes infected leading to chronic dacryocystitis with epiphora and purulent discharge. ${ }^{3}$ It is, however, noticeable that many patients tolerate LDO with epiphora for many years without clinical infection, ${ }^{4}$ representing simple stenosis of lacrimal duct (SSLD).
During the past 20 years there have been only a few studies on the bacteriology of adult LDO. According to them, Staphylococcus epidermidis and Staphylococcus aureus are the most frequently isolated organisms in adult lacrimal sac infections. ${ }^{5-7}$

The treatment of LDO in adults is surgery, either external or endonasal dacryocystorhinostomy (DCR), or occasionally silicone intubation. Walland and Rose ${ }^{8}$ reported a fivefold risk of soft tissue infection after open lacrimal surgery without systemic antibiotic prophylaxis. According to them, postoperative soft tissue infection represents a significant risk of failure in lacrimal surgery. Knowledge of the bacteriology of LDO contributes significantly to the choice of prophylactic antimicrobial agents.

The purpose of this study was to determine the current bacteriology of LDO in Finnish (white) adults and to determine whether the bacteriology of SSLD and chronic dacryocystitis differ from each other.

\section{Materials and methods}

PATIENTS

We examined 118 consecutive adult patients with LDO, who had been referred for lacrimal drainage surgery to the outpatient clinic of the Department of Ophthalmology, Turku University Central Hospital, between April 1994 and November 1995. The patients ranged in age from 22 to 89 (mean 63.5) years; 93 (79\%) were women and $25(21 \%)$ were men. Nine of the 118 patients with LDO were bilateral cases. Eighteen patients had previously had at least one acute episode of dacryocystitis, and seven of them had suffered from two to five acute episodes. Patients who had undergone lacrimal drainage surgery during the past year were excluded. Five patients had had previous external DCR performed 1-24 years earlier and one patient had undergone silicone intubation 1 year earlier. Altogether, 112 patients had not undergone previous lacrimal drainage operations. Informed consent was obtained from all the patients studied.

\section{OPHTHALMIC EXAMINATION}

We performed a routine ophthalmic examination including biomicroscopy, using HaagStreit 900 instruments paying special attention to the presence of discharge and epiphora. The LDO was confirmed by irrigation of the lacrimal drainage system and by probing up to the nasal wall of the lacrimal sac fossa.

\section{BACTERIAL ISOLATION}

In all, 127 samples of the contents of the lacrimal sac were obtained from 118 patients;
Accepted for publication 12 September 1996 
nine of the patients had cultures obtained from both sides. The collection of the samples was performed either by applying pressure over the lacrimal sac and allowing the purulent material to reflux through the lacrimal punctum, or by irrigating the lacrimal drainage system with sterile saline and collecting the sample from the refluxing material. The samples were collected with sterile cotton wool swabs, ensuring that the lid margins or the conjunctiva were not touched. None of the patients had used either antibiotic eyedrops or systemic antibiotics for at least a week before their visit to the outpatient clinic. Anaesthetic eyedrops were not used before the sample collection. The samples were cultured on the day of collection onto blood, chocolate, and fastidious anaerobic agar and incubated aerobically and anaerobically for 4 days. The anaerobic incubation took place in an anaerobic cabinet (Don Whitley, UK). The bacteriological isolates were identified with standard procedures.

\section{STATISTICS}

Fisher's exact fourfold table test was used for comparing the distributions of the isolated micro-organisms between different clinical groups with a $\mathrm{p}$ value $<0.05$ chosen to be statistically significant.

\section{Results}

CLINICAL FINDINGS

A total of $97(76 \%)$ cases showed chronic dacryocystitis with purulent discharge and epiphora. These cases were divided into two subgroups according to the quality of discharge. Forty six cases showed copious purulent discharge or thick mucous discharge coming from the lacrimal sac, and 51 cases showed epiphora and minor mucopurulent discharge only.

Thirty $(24 \%)$ patients complaining of epiphora did not show any clinical signs of infection of the lacrimal drainage system. In all of these, the reflux from the irrigated lacrimal sac was entirely clear tear fluid and saline. Our clinical diagnosis for these 30 cases was SSLD.

BACTERIOLOGICAL FINDINGS

The results of the aerobic and anaerobic cultures of the 118 patients with LDO are presented in Table 1 . Of the 127 samples 107 $(84 \%)$ yielded a positive culture. Of the 107 samples with positive culture results, $51(48 \%)$ had mixed cultures with two to four organisms isolated. Altogether, 156 organisms were isolated. The majority of micro-organisms were Gram positive bacteria. Altogether, $108 \mathrm{Gram}$ positive isolates were recovered, representing $69 \%$ of the overall 156 isolates cultured. Gram positive bacteria were found in 79 samples, accounting for $62 \%$ of all the samples. In 26 of the samples two to three different Gram positive bacteria were present. The most frequently cultured species was Staphylococcus epidermidis, which was isolated in $42(33 \%)$ of the samples, accounting for $27 \%$ of all the isolates. Gram negative bacteria were recovered from 26 samples $(20 \%)$. They represented $17 \%$ of the isolates, the most common Gram
Table 1 Bacteriological findings of the content of the lacrimal sac in 118 adult patients with lacrimal duct obstruction

\begin{tabular}{|c|c|c|c|}
\hline Micro-organisms isolated & $\begin{array}{l}\text { Number of } \\
\text { isolates } \\
(n=156)\end{array}$ & $\begin{array}{l}\% \text { of all } \\
\text { isolates }\end{array}$ & $\begin{array}{l}\% \text { of } \\
\text { samples } \\
(n=127) *\end{array}$ \\
\hline \multicolumn{4}{|l|}{ Gram positive } \\
\hline $\begin{array}{l}\text { organisms: } \\
\text { Staphylococcus }\end{array}$ & 108 & 69.2 & \\
\hline epidermidis & 42 & 26.9 & 33.1 \\
\hline Staphylococcus aureus & 19 & 12.2 & 15.0 \\
\hline Other Staphylococcus & & & \\
\hline sp & 13 & 8.3 & 10.2 \\
\hline Micrococcus sp & 1 & 0.6 & 0.8 \\
\hline Streptococcus & & & \\
\hline рпеитопіае & 8 & 5.1 & 6.3 \\
\hline Other Streptococcus sp & 10 & 6.4 & 7.9 \\
\hline Corynebacterium $\mathrm{sp}$ & 4 & 2.6 & 3.1 \\
\hline Other Gram positive & & & \\
\hline \multirow{2}{*}{\multicolumn{4}{|c|}{ Gram negative }} \\
\hline & & & \\
\hline organisms: & 26 & 16.7 & \\
\hline $\begin{array}{l}\text { Haemophilus influenzae } \\
\text { Haemonhilus }\end{array}$ & 6 & 3.8 & 4.7 \\
\hline $\begin{array}{l}\text { Haemophilus } \\
\text { parainfluenzae }\end{array}$ & 2 & 1.3 & 1.6 \\
\hline Escherichia coli & 3 & 1.9 & 2.4 \\
\hline \multicolumn{4}{|l|}{ Pseudomonas } \\
\hline aeruginosa & 2 & 1.3 & 1.6 \\
\hline Citrobacter sp & 2 & 1.3 & 1.6 \\
\hline Enterobacter $\mathrm{sp}$ & 3 & 1.9 & 2.4 \\
\hline Klebsiella pneumoniae & 2 & 1.3 & 1.6 \\
\hline Moraxella catarrhalis & 1 & 0.6 & 0.8 \\
\hline Morganella morganii & 1 & 0.6 & 0.8 \\
\hline Acinetobacter lwoffii & 1 & 0.6 & 0.8 \\
\hline Proteus sp & 1 & 0.6 & 0.8 \\
\hline \multicolumn{4}{|l|}{ Other Gram negative } \\
\hline rods & 1 & 0.6 & 0.8 \\
\hline Gram negative coccus & 1 & 0.6 & 0.8 \\
\hline Anaerobic organisms: & 20 & 12.8 & \\
\hline Propionibacterium sp & 16 & 10.3 & 12.6 \\
\hline \multicolumn{4}{|l|}{ Other anaerobic Gram } \\
\hline positive rods & 2 & 1.3 & 1.6 \\
\hline Bacteroides fragilis & 1 & 0.6 & 0.8 \\
\hline Fusobacterium $\mathrm{sp}$ & 1 & 0.6 & 0.8 \\
\hline Fungal organisms: & 2 & 1.3 & \\
\hline Candida $\mathrm{sp}$ & 2 & 1.3 & 1.6 \\
\hline Mixed flora & 8 & & 6.3 \\
\hline No micro-organism & 20 & & 15.7 \\
\hline
\end{tabular}

${ }^{\star}$ Number of samples.

negative bacteria being Haemophilus influenzae, which represented $4 \%$ of the isolates. Anaerobic micro-organisms were present in 20 (16\%) samples. They accounted for $13 \%$ of the isolates, the most frequently isolated anaerobic bacteria being Propionibacterium sp, which represented $10 \%$ of the isolates, and $80 \%$ of all the anaerobic isolates.

Both the 30 cases carrying the clinical diagnosis of SSLD, and the 97 cases with chronic dacryocystitis, showed a preponderance of staphylococci, Gram positive rods, Propionibacterium $\mathrm{sp}$, and a few other anaerobic organisms (Table 2). Not a single isolate of streptococci occurred in samples of the cases with SSLD, whereas these organisms were isolated significantly more often $(20 \%)$ in samples of the cases with chronic dacryocystitis $(p=0.004)$. Gram negative organisms were also isolated significantly more often $(26 \%)$ in the cases with chronic dacryocystitis than in the cases with SSLD $(p=0.004)$. There were significantly more cases with SSLD (33\%) than cases with chronic dacryocystitis $(10 \%)$ in which no micro-organism was found $(p=0.005)$. In chronic dacryocystitis both the cases with copious purulent or mucous discharge and those with minor mucopurulent discharge showed Gram positive organisms frequently (Table 3), although these were even more 
Table 2 Bacteriological findings in 30 cases with simple stenosis of the lacrimal duct and in 97 cases with chronic dacryocystitis

\begin{tabular}{|c|c|c|c|}
\hline \multirow[b]{2}{*}{ Micro-organisms isolated } & \multicolumn{2}{|c|}{ Number of isolates (\% of samples) } & \multirow{2}{*}{$\begin{array}{l}p \text { Value } \\
\text { Simple stenosis } \\
v \text { chronic } \\
\text { dacryocystitis }\end{array}$} \\
\hline & $\begin{array}{l}\text { Simple stenosis } \\
(n=30)^{*}\end{array}$ & $\begin{array}{l}\text { Chronic } \\
\text { dacryocystitis } \\
(n=97)^{\star}\end{array}$ & \\
\hline Gram positive organisms: & $16 \dagger$ & $92 \ddagger$ & 0.02 \\
\hline Staphylococci & $13(43.3)$ & $61(62.9)$ & \\
\hline Streptococci & - & $19(19.6)$ & 0.004 \\
\hline Gram positive rods & $3(10.0)$ & $12(12.4)$ & \\
\hline Gram negative organisms: & 1 & 25 & 0.004 \\
\hline Haemophilus sp & $1(3.3)$ & $7(7.2)$ & \\
\hline Enterobacteria & - & $12(12.4)$ & \\
\hline Other Gram negative organisms & - & $6(6.2)$ & \\
\hline Anaerobic organisms: & 5 & 15 & 0.54 \\
\hline Propionibacterium $\mathrm{sp}$ & $4(13.3)$ & $12(12.4)$ & \\
\hline Other anaerobic organisms & $1(3.3)$ & $3(3.1)$ & \\
\hline Yeast & - & $2(2.1)$ & 0.58 \\
\hline No micro-organism & $10(33.3)$ & $10(10.3)$ & 0.005 \\
\hline
\end{tabular}

$\star$ Number of samples.

†Gram positive bacteria found in 13 samples.

¥Gram positive bacteria found in 65 samples.

frequent in the cases with minor mucopurulent discharge $(p=0.03)$. However, about half $(52 \%)$ of the samples of the cases with copious purulent or mucous discharge showed Gram negative organisms, whereas these bacteria were isolated in only one sample $(2 \%)$ of the cases with minor mucopurulent discharge. This difference was statistically highly significant $(\mathrm{p}=0.000)$.

\section{Discussion}

During the past 50 years the microbiological flora of dacryocystitis have gradually changed. The proportion of Streptococcus pneumoniae, which in the 1930s was the most common species cultured after to Staphylococcus epidermidis (albus), ${ }^{3}$ has decreased. ${ }^{579}$ In this study Gram positive bacteria were found in $69 \%$ of the isolates. This is in close agreement with the observation of $65 \%$ of Gram positive organisms by Coden et al. $^{7}$ The most common organisms cultured in our study were Staphylococcus species, accounting for $47 \%$ of the isolates. This percentage compares fairly well with the results of Thicker and Buffam, ${ }^{6}$ Huber-Spitzy et $a l^{5}{ }^{5}$ and Coden et $a l^{7}$ (their

Table 3 Distribution of aetiological agents in 97 cases with chronic dacryocystitis according to quality of discharge

\begin{tabular}{|c|c|c|c|}
\hline \multirow[b]{2}{*}{ Micro-organisms isolated } & \multicolumn{2}{|c|}{$\begin{array}{l}\text { Number of isolates (percentage of } \\
\text { samples) }\end{array}$} & \multirow{2}{*}{$\begin{array}{l}\text { p Value } \\
\\
\text { Copious v } \\
\text { minor } \\
\text { discharge }\end{array}$} \\
\hline & $\begin{array}{l}\text { Copious purulent } \\
\text { or mucous } \\
\text { discharge } \\
(n=46)^{\star}\end{array}$ & $\begin{array}{l}\text { Minor } \\
\text { mucopurulent } \\
\text { discharge } \\
(n=51)^{\star}\end{array}$ & \\
\hline Gram positive organisms: & $40 \dagger$ & $52 \ddagger$ & 0.03 \\
\hline Staphylococci & $26(56.5)$ & $35(68.6)$ & \\
\hline Streptococci & $9(19.6)$ & $10(19.6)$ & \\
\hline Gram positive rods & $5(10.9)$ & $7(13.7)$ & \\
\hline Gram negative organisms: & 24 & 1 & 0.00 \\
\hline Haemophilus sp & $7(15.2)$ & - & \\
\hline Enterobacteria & $12(26.1)$ & - & \\
\hline Other Gram negative organisms & $5(10.9)$ & $1(2.0)$ & \\
\hline Anaerobic organisms: & 10 & 5 & 0.09 \\
\hline Propionibacterium $\mathrm{sp}$ & $8(17.4)$ & $4(7.8)$ & \\
\hline Other anaerobic organisms & $2(4.3)$ & $1(2.0)$ & \\
\hline Yeast & $1(2.2)$ & $1(2.0)$ & 0.73 \\
\hline No micro-organism & $3(6.5)$ & $7(13.7)$ & 0.20 \\
\hline
\end{tabular}

*Number of samples.

+Gram positive bacteria found in 26 samples.

$\ddagger$ Gram positive bacteria found in 39 samples. percentages being $73 \%, 51 \%$, and $49 \%$ respectively). Streptococcus pneumoniae represented $5 \%$ of the isolates in our study, which is higher than Huber-Spitzy et $a l^{5}$ and Coden et $a l^{7}$ reported (their percentages being $2 \%$ and $2.3 \%)$.

Gram negative organisms represented $17 \%$ of the isolates of the total material in this study, the most frequently isolated species being $\mathrm{Hae}$ mophilus influenzae (4\%). Previously, HuberSpitzy et $a l^{5}$ reported Gram negative organisms accounting for $26 \%$ of isolates, the most frequent species being Escherichia coli (12\%). Coden et $a l^{7}$ observed Gram negative organisms in $27 \%$ of all isolates, including Pseudomonas aeruginosa in $9 \%$ and Haemophilus species in $6 \%$ of isolates.

In the cases with chronic dacryocystitis Gram negative organisms were isolated in 26\% of samples in this study. Gram negative organisms occurred statistically highly significantly more frequently in cases with copious purulent or mucous discharge than in cases with minor discharge. This tallies with the practice that chronic dacryocystitis with mucous or purulent discharge is a contraindication for elective intraocular surgery. In lacrimal drainage surgery of such cases the antimicrobial prophylaxis should also cover Gram negative organisms.

In this study anaerobic bacteria were seen in $13 \%$ of the overall 156 isolates, mostly including Propionibacterium species ( $80 \%$ of anaerobic isolates). Previously, anaerobic bacteria have been reported to account for $7 \%$ of isolates, the most frequent anaerobic bacteria being Propionibacterium acnes (67\% of anaerobic isolates). ${ }^{7}$ Thicker and Buffam ${ }^{6}$ found no anaerobic bacteria from the lacrimal sac in their study. Huber-Spitzy et $a l^{5}$ cultured two anaerobic bacteria (one Propionibacterium species and one anaerobic Streptococcus species) from purulent abscesses of the lacrimal sac in their study of 150 patients with acquired dacryocystitis.

Normal flora of human conjunctiva mostly consisted of Gram positive bacteria, which represented up to $97 \%$ of cultured aerobic isolates. ${ }^{10}$ The most common bacterium was Staphylococcus epidermidis, accounting for 57$87 \%$ of isolates, ${ }^{9-12}$ while Streptococcus species accounted only for $6 \%$ of all aerobic isolates of normal conjunctiva. ${ }^{10}$ Gram negative bacteria represented $0-5 \%$ of aerobic isolates. ${ }^{9-12}$ The most frequent anaerobic bacteria in normal conjunctival flora was Propionibacterium species, accounting for $19 \%$ of all isolates and $81 \%$ of all anaerobic bacteria. ${ }^{10}$ An interesting finding in our study was the paucity of Gram negative bacteria and Streptococcus species in the cases with SSLD, suggesting that the bacterial flora of this group are comparable with those of normal conjunctiva. This finding may explain why patients with SSLD did not have an increased risk for endophthalmitis after intraocular surgery. ${ }^{13}$

In conclusion, chronic dacryocystitis in adults was associated with an increased proportion of Gram negative bacteria. These were clearly not related to conjunctival flora. 
These Gram negative bacteria are potential pathogens in postoperative infections, both in intraocular and lacrimal drainage surgery. For this reason antimicrobial prophylaxis in lacrimal drainage surgery should also cover Gram negative rods.

1 Linberg JV, McCormick SA. Primary acquired nasolacrimal technique. Ophthalmology 1986;93:1055-62.

2 Bartley GB. Acquired lacrimal drainage obstruction: an etiologic classification system, case reports, and a review of the literature. Part 1. Ophthal Plast Reconstr Surg 1992;8: 237-42.

3 Traquair HM. Chronic dacryocystitis. Its causation and treatment. Arch Ophthalmol 1941;26:165-80.

4 Linberg JV. Disorders of the lower excretory system. In: Milder B, Weil BA, eds. The lacrimal system. New York: Appleton-Century-Crofts, 1983:1-134.

5 Huber-Spitzy V, Steinkogler FJ, Huber E, ArockerMettinger E, Schiffbänker M. Acquired dacryocystitis: microbiology and conservative therapy. Acta Ophthalmol (Copenh) 1992;70:745-9.

6 Thicker JA, Buffam FV. Lacrimal sac, conjunctival, and nasal culture results in dacryocystorhinostomy patients. Ophthal Plast Reconstr Surg 1993;9:43-6.

7 Coden DJ, Hornblass A, Haas BD. Clinical bacteriology of dacryocystitis in adults. Ophthal Plast Reconstr Surg 1993;9: 125-31.

8 Walland MJ, Rose GE. Soft tissue infections after open lacrimal surgery. Ophthalmology 1994;101:608-11.

9 Seal DV, Barrett SP, McGill JI. Aetiology and treatment of acute bacterial infection of the external eye. $\mathrm{Br} F$ Ophthalmol 1982;66:357-60.

10 Thiel H-J, Schumacher U. Uber die Standortflora der menschlichen Bindehaut: Untersuchungen von 135 Personen unterschiedlichen Alters. Klin Monatsbl Augenheilkd 1994; 205:348-57.

11 Cason L, Winkler CH. Bacteriology of the eye. I. Normal flora. Arch Ophthalmol 1954;51:196-9.

12 Fahmy JA, Moller S, Weis Bentzon M. Bacterial flora of the normal conjunctive. I. Topographical distribution. Acta normal conjunctive. I. Topographical

13 Puustjärvi T. Endophthalmitis following cataract surgery. Clinical aspects and evaluation of risk factors. Publications of the University of Kuopio, Medicine, Original reports $1989 ; 2: 1-204$ 